\title{
Religious and Socioeconomic Implications of Islamic Insurance: A Review
}

\author{
Nursyuhadah Abdul Rahman ${ }^{1}$, Zurul Aisya Osman ${ }^{1}$, Nur Syairah Ani ${ }^{1} \&$ Zulkarnian Ahmad $^{1}$ \\ ${ }^{1}$ Universiti Kuala Lumpur Business School, Universiti Kuala Lumpur, Malaysia \\ Correspondence: Nursyuhadah Abdul Rahman, Universiti Kuala Lumpur Business School, Universiti Kuala Lumpur, \\ Malaysia.
}

Received: April 30, 2019

Accepted: May 30, 2019

Online Published: June 11, 2019

doi:10.5430/ijfr.v10n5p313

URL: https://doi.org/10.5430/ijfr.v10n5p313

\begin{abstract}
In this paper, our purpose is to evaluate religious and socioeconomic implication of Islamic insurance to the society. Islamic insurance i.e. takaful is a form of protection and wealth preservation method based on the principles of mutual cooperation, encompassing the elements of Shari'ah compliancy such as prohibitions of riba (interest/usury), gharar (uncertainty) and maysir (gambling), while upholding the virtue of mudharabah (profit sharing), wakalah (trusted agency), tabarru' (donation/charity) and ta'awun (cooperation). Recently, there are numerous literatures on religious and socioeconomic realms with regards to takaful industry due to the financial product being widely accepted in the modern day. In addition, contemporary scholars made various efforts to study the legality and feasibility of takaful as an alternative to the conventional insurance. Within the legality and feasibility of takaful, it is essential to recognize its implications to the society. As such, this paper reviews the implications of takaful products within the context of religious duty and spiritual fulfilment, at the same time towards the socioeconomic attainment. The finding of this paper embodies that takaful industry indeed substantially influence the religious and socioeconomic behavior, hence influence the society in making decision with regards to protection of their life, family as well as preservation of their wealth. Besides, this paper outlines the benefits and pitfalls of takaful which open the door for improvement. Nonetheless, this paper limits itself to the implications in general context, hence it provides space for a more focused setting in the near future. On the other hand, as this paper is evaluative in nature, review process is done via analysis of the current literature from academic papers, journals and books obtained via library and online research databases.
\end{abstract}

Keywords: takaful, religious, social, economics, implications

JEL Classification: G22, G41, Z12, Z13

\section{Introduction}

Islamic insurance or takaful is the idea of collaboration, fraternity and solidarity of the individuals from the general public who intentionally consent to contribute cash to help a shared objective of giving common monetary guide to others under specific terms and conditions (Mortuza, 2006; Tiwari, Shahbaz \& Hye 2013). According to S. Saaty and Ahmad Ansari (2009), takaful is derived from the Arabic word kafalah, which signifies 'promising one another' or 'joint assurance'. Historically, the advancement of present day takaful was at first embraced in Sudan in 1979 and Malaysia in 1984.

On a fundamental level, takaful framework depends on common co-tasks, obligations, affirmations, insurance and help between gatherings of members that can be concluded as shared protection (S. Saaty \& Ahmad Ansari, 2009; Mungwari, 2018). According to Mansuri (2006), the contract of takaful should be legitimate, the planned targets of the agreement must be in accordance with the standards of the Shari'ah, free from the intrigue (riba), betting (maysir), misrepresentation, pressure and high level of vulnerability (gharar). In addition, the members ought to consent to co-work effectively and pays for commitment so as to secure the necessities.

Study by Patel (2003) illustrated takaful as major components in Islamic finance. In fact, the application of takaful as financial product will lead to achievement of the Maqasid al-Shari'ah and significantly contribute religious, social and economic wellbeing. Indeed, takaful is acknowledged as the second most critical social foundation for Muslim consumers to secure themselves from destitution and hardship. Noteworthy, takaful industry has developed 
significantly, with an expected normal yearly development rate of $25 \%$ versus $10.2 \%$ for the conventional imsurance between year 2004 and 2007 (Essen, 2010; Murshed, 2018).

Henceforth, this paper presents the selected literatures and implications of takaful with regards to religious and spiritual, social and economic enhancement. The review of literatures shall be explaining three areas, beginning with review on the takaful itself as Islamic insurance thus financial product, the concept of religious/spiritual attainment, and then the concept of socioeconomic attainments. This will be followed by a short description on research methodology. The next part which is on result and discussion shall break its content in three areas of implications i.e. the spiritual/religious, the social and the economic implication. Lastly, the conclusion shall summarize the main points and reiterate the important one.

\section{Review of the Literature}

In this part, we review the existing literatures on the principles, mechanisms and current trends of takaful industry, as well as examine the conceptual basis for the spiritual, religious and socioeconomic attainment.

\subsection{Takaful, the Islamic Insurance}

This part is to identify takaful as Islamic insurance encompass the models of mudharabah (profit sharing), wakalah (agency) as well as hybrid of both in its implementation. Literally, 'takaful' is generated from an Arabic root word. 'kafalah' which means “joint guarantee" (Rahman, et. al, 2008; Mustafa, Tourkia \& Ramadan 2017; Taqi, Ajmal \& Ansari 2018) Technically, takaful refers to mutual guarantee or security provided by a group of people living in the same society against a defined risk or catastrophe befalling one's life, property, or any other form of valuable thing (Billah, 1999).

Additionally, takaful mechanism involves the principles of tabarru' (donation) and ta'awun (mutual cooperation) which enable takaful products and operation to be within Shari'ah compliancy. Through the tabarru' principle, the participants donate to the mutual fund in case of no claim being made, while the ta'awun principle ensure that the mutual fund is used to compensate the needy members (Fauzi et. al, 2016; Myeni \& Mvuyana 2018). Furthermore, every takaful structure involves contribution (donation) by the insured party (participant) to the insurer (operator). If any loss occurred, operator will contribute the second donation (according to the actual amount of loss) to the beneficiary (Seyadi, 2015; Tronzano, 2018).

Takaful concerns on the well-being of the society. For this, the objective of takaful itself is to share risk and also loss among the participants, thus fixes it well within the framework of Maqasid al-Shari'ah (Abdullah, 2012). To realize this, takaful involves three types of models in its implementation, namely mudharabah, wakalah and hybrid of both concepts. Under the concept of mudharabah, two (2) parties operate on a joint venture basis, allowing profit sharing basis as per agreed ratio by the participant and the takaful operator.

According to Ali et al. (2008), mudharabah model will involve contribution from participants known as Family Takaful Fund which is channeled into two (2) separate accounts namely; Participant Account (PA) and Participant Special Account (PSA). The savings and investment will be credited into PA, while the donation amount will be credited into PSA. Takaful operator must ensure that all funds from PA and PSA account must be invested in Shari'ah compliant investment products. Should a claim made by participant due to the unexpected losses, funds from PSA will be used. Meanwhile, upon maturity or claim made by participant, PA will be accumulated and paid together with coverage amount from PSA.

Meanwhile, the basic idea in a takaful operation is that for the participants the takaful operator acts as an agent under the principles of wakalah. According to Frenz and Soualhi (2010), investment or savings fund will be channel to PA account while donation fund into PSA. Any surplus and profits from investment is appropriated to the participant and wakalah fees are considered as an income to takaful operator (Abdul Rahman \& Redzuan, 2001). Worth mentioning, the wakalah fees will be charge from participant's contribution and also from the value of investment (Htay \& Zaharin, 2011; Umaru \& Ombugus 2017).

Furthermore, hybrid model is the combination between mudharabah and wakalah models. In this model, the application of wakalah contract is focusing on underwriting specifically while mudharabah contract is focusing on investment purposes. The role of takaful operator is as an agent on behalf of participants. In exchange for managing the funds, the takaful operator received a wakalah fee charged upon the contribution and the mudharabah on the investment (Frenz \& Soualhi, 2010; Tomfort, 2017). According to Soualhi (2008), donation fund in PSA will be channeled to the participants and takaful operator as well while participants also will receive net underwriting surplus. 


\subsection{The Concept of Spiritual and Religious Attainment}

Here, we discuss the conceptual framework of Islam which would enable any Muslims achieve the spiritual and religious attainment. For this, it is inevitable to include Maqasid al-Shari'ah as the ultimate framework.

Takaful has been acquainted as an option with protection to guarantee that individuals can take an interest in takaful which is free from intrigue, vulnerability, and betting. According to Azmi (2005), takaful can be named as moral protection that working under Islamic moral system and henceforth makes the air of a minding and sharing society. The idea and targets set out in takaful are shaped by the destinations of Islamic law concerning the prosperity of the Ummah. Hence the primary target of takaful are to share the hazard among members, and the misfortune to be borne by not an individual, yet shared as needs be with all members, this is the magnificence of takaful which fixes it well with regards to general goals of Shari'ah (Maqasid al-Shari'ah) (Abdullah, 2012; Unaam, Adim \& Adubasim 2018). Since Shari'ah moulds Muslims life, this segment examines how takaful can meet Shari'ah's destinations and infuse the idea of hazard sharing into society.

According to Abdul Aziz (2010), the objectives of Shari'ah in the perspective of wealth are to manage the wealth by adhering to Shari'ah compliance contracts, to ensure transparency in managing the transactions, to provide certainty (Thabat) in ownership before disposing the property, to be just and fair to all involved parties, and to strive to (I'wad) earn profit. From the basic operational model of takaful, it shown that the participants are sharing their potential financial risk by having a contribution into the takaful fund. Therefore, their losses and needs will be protected. This shows that, among participant are sharing both the good and bad moments together and build a strong spirit of brotherhood (Kasim et. al, 2016; Venkatraja, 2018).

There are three (3) general objectives of Shari'ah, specifically the fundamentals (daruriyyat), the reciprocal (hajiyyat), and the endearment (tahsiniyyat). The principal objective, the fundamentals are expects to ensure five (5) values, i.e. (1) the protection of religion (al-din), (2) the protection of dignity or lineage (al-ird), (3) the protection of life (al-nafs), (4) the protection of intellect (al-aql), and (5) the protection of property (al-mal). The second objective, for example the corresponding, is to give extra guidelines to accomplish the five (5) principle esteems talked about above. This second target considers the evacuation of challenges and the advancement of an agreeable life for individuals. The third objective, i.e. embellishment, is to protect others' desirable interests by promoting a more comfortable of human life (Laldin, 2011).

In term of security of life, the idea of takaful, joint certification and common help are well inside the Maqasid al-Shari'ah structure to give protection to the members against any disaster through common help and common sharing of hazard. Referring to Abdullah (2012), it is the privilege and obligations of people to help other people, additionally known the idea of fard kifayah or social commitment that puts duty on the individuals who are competent or happier to help the individuals who are not able or more regrettable off. Besides, through the idea of Tabarru' (donation), the members will be gotten God's elegance and gift in life hereafter.

As conclusion, Maqasid al-Shari'ah is to ensure that we treat others impartially and reasonably and encourage a minding and sharing society while addressing the necessities of the general public. Takaful meets the golas of Shari'ah because it is a Shari'ah affirmed item and it has the components of common protection and shared obligation. The rehearsing the estimations of empathy, collaboration and solidarity in religion will makes the individuals closer to the God.

\subsection{The Concept of Socioeconomic Attainment}

In this part, we discuss the concept of socioeconomic attainment. We start by exploring the meaning and elements of this framework.

The socioeconomic study explores how social norms, ethics and philosophies influence the people's behaviour and performance. In the earlier studies, Diesing (1958) illustrated economic decisions as attempts to maximize the achievement of given goals, while social decisions reflect changing of personalities and social relations towards greater fundamental harmony and stability. While the economic dimension deals with decision making on resources and economic outputs, social dimension emphasizes on more complex and multifaceted features. According to Davis (2004), social dimension includes welfare and quality of life as well as changes which are equitable and inclusive for all members of a society (Haseeb, Abidin, Hye \& Hartani, 2018).

Indeed, contemporary research has emerged to prove that economic and social attainment are equally significant for the well-being of the society. In fact, empirical research has proven that the excessive emphasis on material achievement while neglecting the social well-being is unfavourable to the society. Accordingly, the goals of human dignity, self-respect, brotherhood, social equality and well-being would not be achieved should it not supported by 
socioeconomic justice (Chapra, 2008). In addition, the greater the motivation people have to implement Islamic values on their own decision, and the more effective socio-economic, judicial and financial institutions are in creating a proper environment for the realization of a just socioeconomic order, the lesser may be the role of the state in enforcing the rules of behaviour and realizing the desired social goals. (Chapra, 2008)

As a result, contemporary Muslims have become increasingly aware of the need to rearrange everyday socioeconomic aspects of life in accordance with Shari'ah's orders and thus, Islamic financial products which is essentially part of the Shari'ah system are structured and endorsed (Laldin \& Furqani, 2013). In general, Islamic finance is fundamentally motivated by the essence of brotherhood, cooperation, social equality, justice, fair allocation of resources, elimination of poverty, protection of the environment and the achievement of general well-being (Laldin \& Furqani, 2013). In order to realize those objectives, the means instituted by the Shari'ah include facilitating financial contracts, establishing values and standards as well as inculcating a sense of social responsibility.

Within the context of takaful, the socioeconomic dimensions encompass the economic sovereignty via equitable distribution of wealth, investment opportunity as well as reduction of poverty gap and inequality, concurrent with social preservation via social justice and security. For instance, general takaful provide a form of Shari'ah-compliant risk management as a means of protection due to event of unavoidable misfortunes. This compensate someone who lose means of happiness in life while help them cover the necessary expenditures. Meanwhile, family takaful play significant role in sustaining the socioeconomic development and as part of a savings and investment instrument (Rahman et. al, 2008). Being specifically designed to fit into the Islamic economic paradigm, takaful upholds the concept of moral and social values while eliminating elements like interests, risks uncertainty, gambling and punishment, which is dampen the socioeconomic attainment.

\section{Research Methodology}

This paper is involves reviewing the concepts and applications based on existing literatures. Analysis is done via reviewing the literatures as well as current practice as for the resources, we fully utilized secondary resources obtained from online library searches which provides us the academic journals and offences.

\section{Results and Discussion}

In this part, we establish discussion on the feasibility and analyses of the implications of takaful to the society. For this, we divide the discussion into three (3) parts, namely the spiritual and religious, social as well as economic implication of takaful implementation.

\subsection{The Spiritual and Religious Implication of Takaful}

In this section, we discussed the spiritual and religious implication of takaful. Our analysis will focus on the elements of tabarru', ta'awun, and prohibitions of riba, gharar and maysir.

The fundamentals of humanity and sharing each other's hardship will assuredly stretch out protection to the affluent individuals from the network. In the takaful model, tabarru' can be utilized for waqf and assets can be diverted into undertakings which are for the benefit of everyone, for example, building new school, emergency clinic or mosques. By considering the standards of decency, straightforwardness, effortlessness and sharing the weight, takaful interests to the very enormity of the human soul (Ahmed, zin \& Majid, 2016; Ferguson, 2008). Subsequently, takaful is basically intended to enable the general public to take care of their concern by offering security to their life and help them in the seasons of requirements and foreseeing the future vulnerabilities. In this manner, it is safeguarded necessities components in maqasid al-Shari'ah of life, ancestry and insightfulness.

Takaful practices are free from the components of riba' (usury) and other restricted components and are advanced around the components of mudharabah, tabarru', and other Shari'ah supported components contrast with customary protection may include riba and some different components which may not be legitimized by Shari'ah specialists (Miller \& Anwar, 2009). If riba' can be withstand through what which is legal, and avoid what is haram, the riches will be honoured and advantageously in this world and the great beyond. This will assist the human with cleansing the substance in day by day life for insurance as well as a feature of ibadah.

In addition, understanding that rights and commitments are indication of human respect in all major legitimate customs and Shari'ah, takaful give assurance to shielding the obligations and privileges of the Muslims (Kamali, 2007). Therefore, takaful enable a Muslim to perform obligations towards the only God and his locale by disposing of damage and giving advantage. Through this, man will cleanse their soul from negative thinking towards their futures and fate, and this will provide peace of mind to do more ibadah to gain more of God's blessing. 
In conclusion, the spiritual and religious implications indicated that participant communicate religious identities to others and express the intensity of beliefs through their consumption choices (Cosgel \& Minkler, 2004). Indeed, the Muslim's religiosity significantly influences their participation attitude towards takaful, and vice versa the participations in takaful goes back influencing the religious and spiritual attainment of the individual Muslim.

\subsection{The Social Implication of Takaful}

Based on the concept of social solidarity, cooperation and joint compensation among members, they are agreed to share together their responsibility of loss that may harm any of participant. This concept is aligned with (Hussain \& Pasha, 2011) mentioning that the contract of takaful itself promote solidarity among participants in respect of any loss in life, business and property.

According to Patel (2004), takaful is an effective tool to minimize any risk exposure from the impacts of disease, theft, disability, and other hazards. It can also help to safeguarding the productive use of income, savings and credit facilities. Takaful is recognized as an important component of any strategy to alleviate poverty. Without protection from losses and natural hazards, people will return to poverty on a regular basis, which is not only depressing, but also will cause a negative impact in the long term.

According to Rahman et al. (2008), takaful has reached the standard of being a necessity nowadays, just like any other necessity in life such as food. Beside the elements of protection, takaful products also provide savings option which makes it more attractive and beneficial to participants in life and after death. Within his lifetime of being insured, takaful provides assurance of funds for children's education, retirement needs, medical expenses, and assistance during hardship. On the other hand, in the event of the participant's decease, his/her contributions would be allocated to ease the burden of beneficiaries.

With takaful, the society achieves improvement in their standard of living, thus providing a more secured and optimistic future. Besides, takaful also enrich the cooperation and responsibility to look after each other in the society. In addition, takaful also act as a mechanism for risk sharing which leads to a peace of mind impact due to an effective protection against losses and also as poverty alleviation mechanism.

\subsection{The Economic Implication of Takaful}

Analysis on the economic implication of takaful focuses two important virtues within its implementation i.e. mudharabah, and tabarru'. Essentially, the emergence of takaful as Islamic cooperative insurance was due to Muslim consumers' desire to have protection which is in conformity with the Shari'ah guideline. In this way, outcome from the takaful plan is the removal of the elements of interest (riba), gambling (maysir), uncertainty (gharar) and other prohibited (haram) elements. It is noteworthy that the Islamic prohibitions are not only religious, but also economically profound.

Within the principles of the mudharabah (profit-sharing) whereby the insurer as well as the assured or his beneficiaries share the profits, bonus and dividends accordingly, takaful has important implications towards partnership, mobilizing financial resources, and sharing risk or monetary loss (Cebeci, 2012). On the other hand, the element of tabarru' (donation) in takaful protects from unexpected future loss while if there is no occurrence of loss, the premiums paid by the insured will be considered as tabarru' and will be non-refundable. (Billah, 1998). The establishment of cooperation, in which the benefit-sharing proportion made known and concurred in advance, enable contracts to be executed with trust and dignity while both sides, the insurer and the insured both gains without reflecting monetary despair to each other. At the same time, by sharing the burden of loss, takaful is also deemed just and equitable.

Moreover, the incorporation of tabarru' (donations or gift) in takaful is a mechanism to help the society eliminate both the element of gambling (maysir) and uncertainty (gharar) (Rahman et. al, 2008). Conventional insurance works on the concept of risk transfer in exchange for a premium by a policyholder, which is seen as a game of uncertainty within Shari'ah view. In addition, the fact that the insurance company invests the premiums for further profits is seen as exploiting the policyholder by making money. On the other hand, the principles of mudharabah embedded in takaful signify sharing of responsibility among the partners thereby risk is diversified and shared by all parties of the contract (Cebeci, 2012). Hence, risk diversification enables the takaful holder to manage his wealth appropriately.

Mahmood (1991) identified the economics implication of riba' as slowing down economic growth, hinder entrepreneurship activities and raise cost of loans which ultimately passed on to the consumers consequently lead to high inflation. Meanwhile, Rahman et. al, (2008) observes a positive trend seemed to appear between the performance of the takaful industry and its effect on the economy. Hence, the establishment of takaful operator 
achieves the economic objective of eradicating poverty by providing employment to society, thus achieves the business and shari'ah objective. In addition, it is also partly act as saving and investment option thus inducing accumulation and preservation of wealth.

Meanwhile, takaful also provides opportunity to accumulate and preserve wealth. This is done when takaful operators invest their funds into halal projects consequently improve the wealth of the Muslim community (Bekkin, 2007). Indeed, the Islamic jurisprudence had approved the idea of a pension scheme for the reason of ensuring security for the subscriber himself as well as his family in cases of difficulty or death (Billah, 1998). It is evident here that takaful is meant as an alternative for the insured to accumulate and preserve wealth in line with Shari'ah's rulings.

\section{Conclusion}

Takaful has become an attractive alternative to conventional insurance as a mechanism to mitigate risk, but at the same time it adheres to religious principle. As conventional insurance contradicts to the Shari'ah due to elements of Gharar (excessive uncertainty), Riba (interest), and Maysir (gambling), the applications of the takaful system has avoided those elements and provide a transparency as well as fair contract (Lim et. al, 2010). It was founded that takaful penetration and density are still low, its rapid growth and optimistic future expansion have raised concern regarding the influential factors behind Takaful participation and demand worldwide. Hence, a growing number of studies have been carried out to explain the effect of different factors that could give an implication to socioeconomics thus influences the society's behavior and outcome not only within religious and spiritual dimension, but also socioeconomics domain.

However, there are still many challenges in the future for the takaful industry to grow nationally and internationally and to date, studies on takaful have not discussed in detail the issues of religion and spiritual. Researchers have not investigated religion and spiritual in many details beyond the main point that takaful as an alternative insurance that complies with religious tents. Future study suggested focusing on the impact of religious and spiritual on takaful demand. This would help for the best reasons of takaful demand and performances. According to Al Mahi (2017), religion is one of the most influential factors on individual behavior. Now when we consider religion at the individual level, the consideration of religiosity is more pertinent. This is because religion is a collective phenomenon, while individuals show different levels of knowledge, affection, or religious activities in their life. Such dimensional segregation and measurement are expected to provide a better understanding of the issue.

\section{References}

Abdulaziz, A. (2010). Al-Dhara'i and Maqasid al-Shari'ah: A case study of Islamic Insurance. Intellectual Discourse, $18(2), 261-281$.

Abdullah, N. I. (2012). Analysis of demand for family Takaful and life insurance: A comparative study in Malaysia. Journal of Islamic Economics, Banking and Finance, 8(4), 67-86.

Abdullah, S. (2012). Risk management via Takaful from a perspective of Maqasid of Shariah. Procedia-Social and Behavioral Sciences, 65, 535-541. https://doi.org/10.1016/j.sbspro.2012.11.161

Ahmed, U., Zin, M. L. M., \& Majid, A. H. A. (2016). Impact of Intention and Technology Awareness on Transport Industry's E-service: Evidence from an Emerging Economy. IJIDB, 7(3), 13-18. https://doi.org/10.13106/ijidb.2016.vol7.no3.13

Akram Laldin, M., \& Furqani, H. (2013). Developing Islamic finance in the framework of maqasid al-Shari'ah: Understanding the ends (maqasid) and the means (wasa'il). International Journal of Islamic and Middle Eastern Finance and Management, 6(4), 278-289. https://doi.org/10.1108/IMEFM-05-2013-0057

Al Mahi, A. S. M. M., Sim, C. S., \& Hassan, A. F. (2017, January). Religiosity and Demand for Takaful (Islamic Insurance): A Preliminary Investigation. International Journal of Applied Business and Economic Research, 15(24), 485-499.

Ali, E. R. A. E., Odierno, H. S. P., \& Ismail, A. (2008). Essential Guide to Takaful: Islamic Insurance. CERT Pubs. Sdn. Bhd.

Amin, H. (2011). Determinants of Islamic Insurance Acceptance: An Empirical Analysis. International Journal of Business \& Society, 12(2).

Azmi, S. (2005). An Islamic approach to business ethics.

Bekkin, R. I. (2007). Islamic insurance: national features and legal regulation. Arab Law Quarterly, 21(1), 3-34. 
https://doi.org/10.1163/026805507X197820

Billah, M. M. (1998). Islamic insurance: Its origins and development. Arab Law Quarterly, 13(4), 386-422. https://doi.org/10.1163/026805598125826201

Billah, M. M. S. (1999). Quantum of Damages in Takaful (Islamic Insurance): A Reappraisal of the Possibility of Adopting the Doctrines of Al-Diyah and Al-Daman. Arab Law Quarterly, 14(4), 339-360. https://doi.org/10.1163/026805599125826543

Cebeci, I. (2012). Integrating the social maslaha into Islamic finance. Accounting Research Journal, 25(3), 166-184. https://doi.org/10.1108/10309611211290158

Coşgel, M. M., \& Minkler, L. (2004). Religious identity and consumption. Review of Social Economy, 62(3), 339-350. https://doi.org/10.1080/0034676042000253945

Davis, G. (2004). A history of the social development network in The World Bank, 1973-2003 (No. 31618). The World Bank.

Diesing, P. (1958). Socioeconomic decisions. Ethics, 69(1), 1-18. https://doi.org/10.1086/291187

Essen, Y. (2010). Challenges Abound for the Takaful Industry. London: Islamic Finance News.

Fauzi, P. N. F. N. M., Abd Rashid, K., Sharkawi, A. A., Hasan, S. F., Aripin, S., \& Arifin, M. A. (2016). Takaful: A review on performance, issues and challenges in Malaysia. Journal of Scientific Research and Development, $3(4), 71-76$.

Ferguson, T. (2008). Takaful 2.0. Using the Power of the Web to Realize the Global Holy Qur'an. Text, Translation and Commentary. By Abdullah Yusuf. Ali Sartaj Company,

Frenz, T., \& Soualhi, Y. (2010). Takaful and retakaful: advanced principles and practices. Islamic Banking and Finance Institut Malaysia (IBFIM).

Haseeb, M., Abidin, I. S. Z., Hye, Q. M. A., \& Hartani, N. H. (2018). The Impact of Renewable Energy on Economic Well-Being of Malaysia: Fresh Evidence from Auto Regressive Distributed Lag Bound Testing Approach. International Journal of Energy Economics and Policy, 9(1), 269-275.

Htay, S. N. N., \& Zaharin, H. R. (2011). Critical analysis on the choice of Takaful (IslamicInsurance) operating models in Malaysia.

Hussain, M. M., \& Pasha, A. T. (2011). Conceptual and operational differences between general takaful and conventional insurance. Australian Journal of Business and Management Research, 1(8), 23-28.

Kamali, M. H. (2007). November. Human dignity in Islam. In International Conference onPathways of Human Dignity: From Cultural Tradition to a New Paradigm.

Kasim, N., Htay, S. N. N., \& Salman, S. A. (2016). The Religious Perspective of Takaful as Ethical Insurance. Mediterranean Journal of Social Sciences, 7(4), 96. https://doi.org/10.5901/mjss.2016.v7n4p96

Laldin, M. A. (2011). Introduction to Shari'ah \& Islamic Jurisprudence. CERT Publication Sdn. Bhd., Kuala Lumpur. https://doi.org/10.12816/0001115

Laldin, M. A., \& Furqani, H. (2013). The foundations of Islamic finance and the Maqāṣid Al-Sharî̀ah requirements. Journal of Islamic Finance, 2(1).

Lim, J., Idris, M. F., \& Carissa, Y. (2010, June). History, progress and future challenge of Islamic. 2010 Oxford Business \& Economics Coference Program.

Mahmood, N. R. (1991). Takaful: The Islamic system of mutual insurance: The Malaysian experience. Arab Law Quarterly, 280-296. https://doi.org/10.2307/3381379

Mansuri, M. T. (2006). Islamic Law of Contract and Business Transactions. New Delhi, India: Adam Publishers \& Distributors.

Md Husin, M., \& Ab Rahman, A. (2013). What drives consumers to participate into family takaful schemes? A literature review. Journal of Islamic Marketing, 4(3), 264-280. https://doi.org/10.1108/JIMA-04-2012-0019

Millar, R., \& Anwar, H. (Eds.). (2009). Islamic finance: A guide for international business and investment. Blue Ibex.

Mortuza, A. K. (2006). Present Scenario and Future Potentials of Takaful. Journal of Islamic Economics, Banking 
and Finance, 2(2), 1-14.

Mungwari, T. (2018). Media framing of ZANU PF Internal Succession Struggles: Mnangagwa and the Military Factor. American Journal of Social Sciences and Humanities, 3(1), 1-21. https://doi.org/10.20448/801.31.1.21

Murshed, M. (2018). International Tourism Demand in Bangladesh: An ARDL Bounds Test Approach. Journal of Tourism Management Research, 5(1), 50-67. https://doi.org/10.18488/journal.31.2018.51.50.67

Mustafa, H. M., Tourkia, F. B., \& Ramadan, R. M. (2017). An Overview on Evaluation of E-Learning/Training Response Time Considering Artificial Neural Networks Modeling. Journal of Education and e-Learning Research, 4(2), 46-62. https://doi.org/10.20448/journal.509.2017.42.46.62

Myeni, S. L., \& Mvuyana, B. Y. (2018). Participatory Processes in Planning for Self-Help Housing Provision in South Africa: Policies and Challenges. International Journal of Public Policy and Administration Research, 5(1), 24-36.

Patel, S. (2003). Takaful and Poverty Alleviation. United Kingdom: The International Cooperative and Mutual Insurance Federation (ICMIF).

Patel, S. (2004). Takaful and poverty alleviation. European Economic Review, 48(5), 1-21. https://doi.org/10.1016/j.euroecorev.2004.01.003

Rahman, Z. A., \& Redzuan, H. (2009). Takaful: The 21st Century Insurance Innovation. McGraw-Hill (M).

Rahman, Z. A., Yusof, R. M., \& Bakar, F. A. (2008). Family takaful: it's role in social economic development and as a savings and investment instrument in Malaysia - an extension. Syariah Journal, 16(1), 89-105.

Saaty, A. S., \& Ahmad Ansari, Z. (2009). Takaful-An Islamic Way of Insurance-Developments, Challenges and Issues.

Seyadi, R. M. (2015). Legal Aspect of Islamic Finance. Arab Law Quarterly, 29(3), 285-295. https://doi.org/10.1163/15730255-12341302

Fortune, S. (2010, October). Takaful/Islamic Insurance.

Soualhi, Y. (2008). Shari'ah Inspection in Surplus Distribution: Shari'ah Views and their Current Implementation. Unpublished Research Paper, International Shari'ah Research Academy, Islamic Finance Seminar (IIFS).

Taqi, M., Ajmal, M., \& Ansari, M. S. (2018). Financial efficiency of India tourism development corporation (ITDC) limited: An empirical study. Journal of Tourism Management Research, 5(1), 14-22. https://doi.org/10.18488/journal.31.2018.51.14.22

Tiwari, A. K., Shahbaz, M., \& Hye, Q. M. A. (2013). The environmental Kuznets curve and the role of coal consumption in India: cointegration and causality analysis in an open economy. Renewable and Sustainable Energy Reviews, 18, 519-527. https://doi.org/10.1016/j.rser.2012.10.031

Tomfort, A. (2017). The Japanese asset price bubble: Evolvement and consequences. Asian Journal of Economics and Empirical Research, 4(2), 132-141. https://doi.org/10.20448/journal.501.2017.42.132.141

Tronzano, M. (2018). The Expectations Hypothesis of the Term Structure in the Philippines: An Empirical Note (2001-2017). Asian Economic and Financial Review, 8(5), 704-716. https://doi.org/10.18488/journal.aefr.2018.85.704.716

Umaru, R. I., \& Ombugus, D. A. (2017). Determinants of job satisfaction of Colleges of Education Lecturers: A study of Nasarawa State College of Education, Akwanga. Asian Business Research Journal, 2(1), 8-13. https://doi.org/10.20448/journal.518.2017.21.8.13

Unaam, A. O., Adim, C. V., \& Adubasim, E. I. (2018). Employee Loyalty and Organizational Citizenship Behaviour in the Port Harcourt Area Command of the Nigeria Police Force. International Journal of Business, Economics and Management, 5(6), 135-145. https://doi.org/10.18488/journal.62.2018.56.135.145

Venkatraja, B. (2018). Sensitivity of Trade Balance to Exchange Rate Depreciation: Evidence from Indo-US Bilateral Trade. Asian Economic and Financial Review, 8(5), 691-703. https://doi.org/10.18488/journal.aefr.2018.85.691.703

World's Biggest Islamic Bank Directory. (n.d.).Retrieved from http://shariah-fortune.com/ 